\title{
THE EFFECT OF THE LUNAR PHASE ON THE CATCH PER UNIT EFFORT (CPUE) OF THE TURKISH SWORDFISH LONGLINE FISHERY IN THE EASTERN MEDITERRANEAN SEA
}

\author{
Tevfik CEYHAN ${ }^{*}$, George TSERPES ${ }^{2}$, Okan AKYOL ${ }^{1}$, and Panagiota PERISTERAKI² \\ ${ }^{1}$ Faculty of Fisheries, Ege University, Bornova, Izmir, Turkey \\ ${ }^{2}$ Institute of Marine Biological Resources, Hellenic Centre for Marine Research, Thalassocosmos, Heraklion, Crete, \\ Greece
}
Ceyhan T., Tserpes G., Akyol O., Peristeraki P. 2018. The effect of the lunar phase on the catch per unit effort (CPUE) of the Turkish swordfish longline fishery in the eastern Mediterranean Sea. Acta Ichthyol. Piscat. 48 (3): 213-219.

Background. The swordfish, Xiphias gladius Linnaeus, 1758, is a pelagic and highly migratory species distributed in the Atlantic, Indian, and Pacific oceans as well as in the Mediterranean Sea. Swordfish fishing has been carried out in the Mediterranean with longlines, gillnets, harpoons, and traps since the Roman times. Although information is available on the influence of the lunar phase on the catch per unit effort (CPUE) for the swordfish longline fishery in the Atlantic and Pacific oceans, the data concerning the Mediterranean is rather limited. The aim of this study was to examine the relation between the lunar phase and the swordfish CPUE, based on data from Turkish longline fisheries, targeting swordfish in the eastern Mediterranean during the 2008-2016 fishing seasons.

Material and methods. We monitored randomly the daily fishing activity of longliners based at the ports of Fethiye and Özdere during 2008-2016. A total of 86 surveying operations were carried out, including 79 in the area between Fethiye and Alanya, the remaining ones were in Özdere in the southern Aegean coasts along the eastern Mediterranean Sea. The effect of the lunar phase on the swordfish catch rates, expressed in terms of $\mathrm{kg}$. 1000 hooks $^{-1}$, was examined by means of the Generalized Additive Modelling (GAMs) techniques.

Results. The observed CPUE rates ranged from 0 to $700 \mathrm{~kg} \cdot 1000$ hooks $^{-1}$. The mean swordfish CPUEs in the dark and light periods of the lunar cycle were equal to $178.10 \pm 19.01$ and $175.27 \pm 19.56 \mathrm{~kg} \cdot 1000$ hooks $^{-1}$, respectively. Although no significant differences among phases of the Moon were found $(P>0.05)$, CPUEs differed significantly between years $(P<0.05)$.

Conclusion. It seems that the mechanism linking swordfish CPUE variations with the lunar cycle involves several factors, making difficult the identification of direct relations. Further studies are needed to better clarify the impact of the lunar phase on the longline gear, considering also additional parameters, such as light transition, prey abundance, physico-chemical characteristics of the marine environment, and the soak time of the gear.

Keywords: swordfish, Xiphias gladius, lunar effect, lunar phase, phase of the Moon, catch rates, Aegean Sea, Mediterranean

\section{INTRODUCTION}

Swordfish, Xiphias gladius Linnaeus, 1758, is a pelagic and highly migratory species and it is distributed in the Atlantic, Indian, and Pacific oceans as well as the Mediterranean Sea. Nakamura (1986) stated that there are two types of migrations for highly migratory species. One that is passive, which is the movement within a habitat in response to local biotic and abiotic conditions, and one that is active, in which the fish move from one habitat to another, following an ontogenetic change resulting from a biological requirement motivated by the need to feed and reproduction. Therefore, swordfish are subjects to horizontal and vertical shifts being this behaviour associated with prey location at a depth range of 0-1500 $\mathrm{m}$ (Lerner et al. 2013). Besides, migrating toward temperate or cold waters in the summer and back to warm waters in the fall, having hightemperature tolerance ranging from 5 to $27^{\circ} \mathrm{C}$ (Tserpes et al. 2003, Dewar et al. 2011, Froese and Pauly 2018).

Swordfish fishing has been carried out in the Mediterranean with longlines, gillnets, harpoons, and traps since the Roman times. Swordfish has been also acquired as bycatch in other fisheries such as longlines and driftnets targeting albacore, purse seines, etc. (Anonymous 2017b). The reported annual catches in the Mediterranean over the last two decades were on average about $13057 \mathrm{t}$ (Anonymous 2017a). Historically, the main fishing gears 
used have been surface longlines, representing on average $88 \%$ of the annual catch, and gillnets. However, gillnets were completely eliminated in the Mediterranean in 2012 and over the last 25 years the biomass levels of swordfish appear to be rather stable, but representing low levels (Anonymous 2017b). Moreover, the stock is currently 'overfished' and 'suffering overfishing'. According to the objectives of the International Commission for the Conservation of Atlantic Tunas (ICCAT), the stock requires rebuilding and fishing mortality has to be reduced.

Although information is available on the influence of the lunar phases on the CPUEs of the swordfish longline fishery in the Atlantic (Draganik and Cholyst 1987, Moreno et al. 1991, Neves dos Santos and Garcia 2005, Orbesen et al. 2017) and the Pacific oceans (Bigelow et al. 1999), the information concerning the Mediterranean is rather limited (de la Serna et al. 1992, Di Natale and Mangano 1995, Damalas et al. 2007). In Turkey, Akyol (2013) has done the first study about the lunar phase effect on gillnets targeting swordfish.

In this paper, we attempted to determine the lunar phase influence on the swordfish catch per unit effort (CPUE), based on data from Turkish longline fisheries targeting swordfish in the eastern Mediterranean during the 2008-2016 fishing seasons.

\section{MATERIAL AND METHODS}

We randomly monitored the daily fishing activity of longliners based at the ports of Fethiye and Özdere during 2008-2016. During those operations, the involved scientists were present on board of the vessels. There were 10-12 vessels in the region, that used longline to target swordfish. Therefore, nine swordfish vessels were randomly selected during the surveys. The surveyed boats ranged from 6 to $14 \mathrm{~m}$ (mean $9.8 \pm 1.0 \mathrm{~m}$ ) in length (LOA); 9 to $268 \mathrm{~kW}$ (mean $79.7 \pm 27.8 \mathrm{~kW}$ ) in machine power. The number of hooks used in swordfish longlines ranged from 130 to 670 (mean $595 \pm 20.85$ ), while the main line was between $1.8 \mathrm{~km}$ and $40 \mathrm{~km}$ (mean $30.3 \pm 1.06 \mathrm{~km}$ ). A total of 86 surveying operations were carried out between Fethiye and Alanya (79) and Özdere (7) in the southern Aegean coasts along the eastern Mediterranean Sea (Fig. 1). The data collected during each fishing trip included:

- Date, fishing area, and depth

- Fishing gear aspects such as total number of hooks, the total length of the main line, bait type

- The weight of the catch by species

Seven fishing areas and five different bait types were defined (Fig. 1).

The limited number of observations did not allow us to classify the lunar cycle in detailed categories for the subsequent modelling. Thus, the lunar cycle was classified into two periods of light and dark. The demi lunes (first/last quarters), waning gibbous, and full Moon were considered as the light period, while the new Moon and the crescent were incorporated into the dark period. The effect of lunar phase on the swordfish catch rates, expressed in terms of $\mathrm{kg} \cdot 1000$ hooks ${ }^{-1}$, was examined by means of the Generalized Additive Modelling (GAMs) techniques (Hastie and Tibshirani 1990).

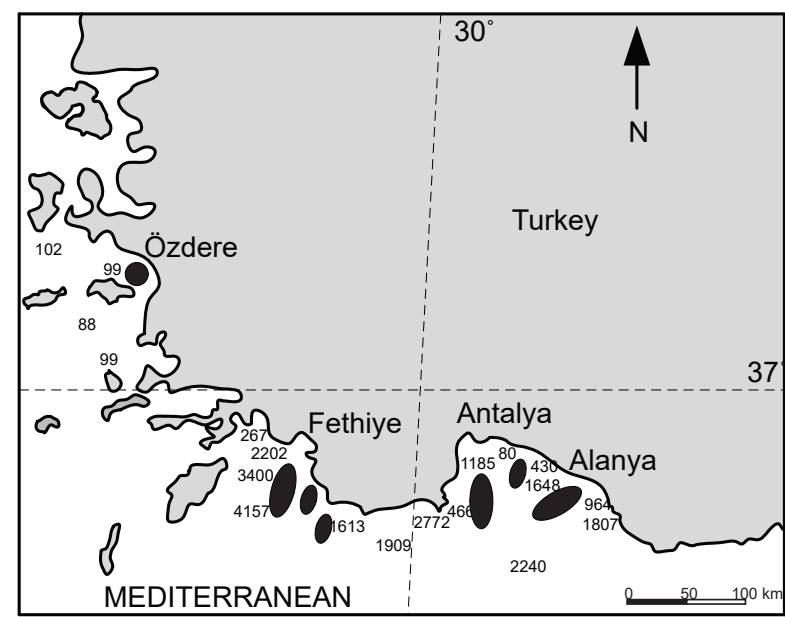

Fig. 1. The sampling areas (black ovals) of swordfish, Xiphias gladius, along the south-eastern coasts of Turkey (Mediterranean); the numbers indicate depth in $\mathrm{m}$

The main advantage of GAMs over traditional regression methods was their capability to model non-linear relations between a response variable and multiple explanatory variables using non-parametric smoothers. In the presently reported case, the non-linear predictors included the depth, sea surface temperature (SST), month, and the year of sampling. In addition, bait type and fishing area were considered as factor variables. In this way, other parameters, apart from the lunar phase, that could influence catch rates were also considered.

Given the existence of few zero catches, a Tweedie GAM following a compound Poisson-gamma approach was applied. This avoids multiple-stage modelling of zeroinflated data and allows to model jointly the probability of presence and the non-zero sampled quantity (Shono 2008, Lecomte et al. 2013). The smoother function used was a penalized cubic regression spline and model fitting was accomplished using the "mgcv" library (Wood 2006) under the $\mathrm{R}$ language environment ( $\mathrm{R}$ Core Team 2017). The procedure automatically selects the degree of smoothing based on the Generalized Cross Validation (GCV) score, which is a proxy for the model predictive performance. However, given the limited number of observations, the model was constrained to be at maximum a quartic relation. Hence, the maximum degrees of freedom for each smoothing term, measured as the number of knots $(k)$, was set to 4 (i.e., $k=5$ in the GAM formulation). A log link function was assumed and deficiencies of the fitted model were diagnosed by means of randomised quantile residual plots (Foster and Branvington 2013).

Thus, the general form of the GAM used was

$\mathrm{CPUE} \sim a+\mathrm{MP}+A+\mathrm{BT}+s(Y)+s(M)+s(D)+s(\mathrm{SST})+e$

where, $a$ is the intercept, MP is moon phase, $A$ is area, BT is bait type, $Y$ is year, $M$ is month, $D$ is depth, SST is sea surface temperature and $s$ indicates the smoother function of the corresponding independent variable and $e$ is a random error term.

Statistical inference was based on the $95 \%$ confidence level. 


\section{RESULTS}

The observed CPUE rates ranged from 0 to $700 \mathrm{~kg}$. 1000 hooks $^{-1}$ and the mean CPUE was $176.09 \pm 14.93 \mathrm{~kg}$. 1000 hooks $^{-1}$. Summary statistics by lunar phase are shown in Table 1. Exploratory analysis revealed large variations between years regarding the median CPUE estimates (Fig. 2) while boxplots of CPUE by lunar phase are highly overlapping (Fig. 3).

Table 1

Summary of catch per unit effort (CPUE) statistics of the longline fishery of swordfish, Xiphias gladius, along the south-eastern coasts of Turkey in relation to Moon phases

\begin{tabular}{lrrrrrr}
\hline \multirow{2}{*}{$\begin{array}{l}\text { Moon } \\
\text { phase }\end{array}$} & \multicolumn{5}{c}{ CPUE $\left[\mathrm{kg} \cdot 1000\right.$ hooks $\left.^{-1}\right]$} \\
\cline { 2 - 7 } & $N$ & Mean & Range & \multicolumn{1}{c}{ SD } & \multicolumn{1}{c}{ SE } & Median \\
\hline Dark & 24 & 178.10 & $40.00-357.14$ & 93.15 & 19.01 & 186.50 \\
Light & 60 & 175.27 & $0-700.00$ & 151.54 & 19.56 & 150.00 \\
\hline
\end{tabular}

$\mathrm{SD}=$ standard deviation, $\mathrm{SE}=$ standard error of the mean, $N=$ number of fishing operations.

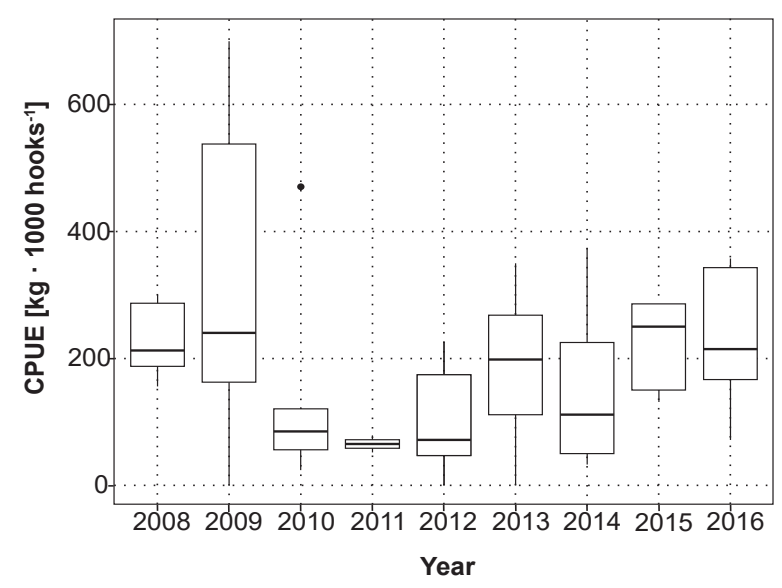

Fig. 2. Catch per unit effort (CPUE) values for of the surface longline fishery of swordfish, Xiphias gladius, along the south-eastern coasts of Turkey by year

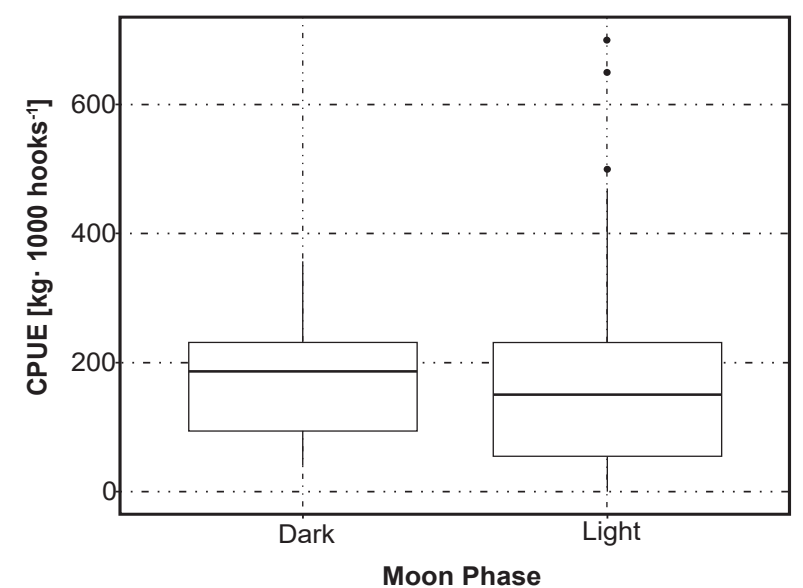

Fig. 3. Catch per unit effort (CPUE) values for of the surface longline fishery of swordfish, Xiphias gladius, along the south-eastern coasts of Turkey by Moon phase
The randomized quantile residual plot of the applied GAM model did not show any outstanding feature that would suggest inappropriateness of the fitted model (Fig. 4). The analysis of deviance table indicated that only the effect of year was significant (Table 2) and from the yeareffect plot, it appears that CPUE is decreasing up to 2012 remaining rather stable afterwards (Fig. 5).

\section{DISCUSSION}

In general, CPUE is used as an index of abundance, meaning that a proportional change in CPUE is expected to represent the same proportional change in stock size (Anonymous 1999). Ideally, an abundance index should be fishery independent. In fact, CPUE is commonly obtained from commercial fishery-dependent data. CPUE rates can be influenced by many factors such as fleet dynamics, schooling behaviour, gear selection, and seasonal and spatial

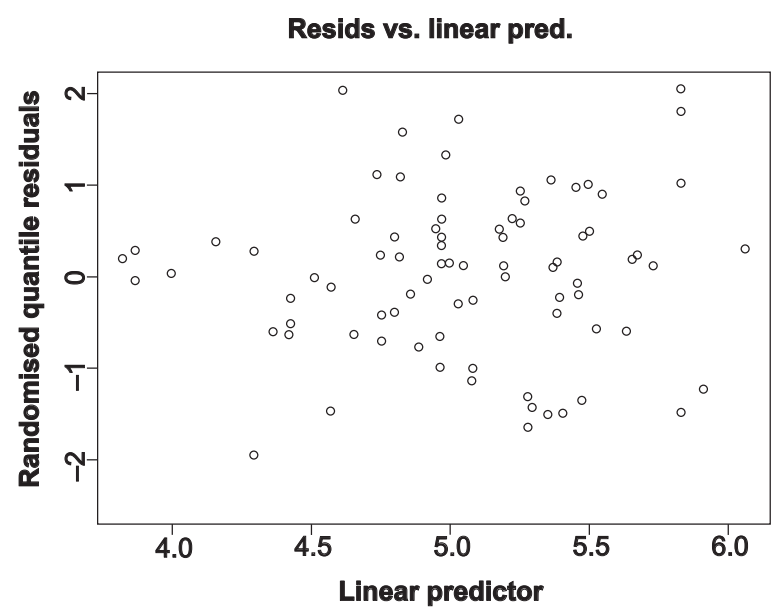

Fig. 4. Randomised quantile residual plot of the GAM model fitted to the catch per unit effort (CPUE) data for of the surface longline fishery of swordfish, Xiphias gladius, along the south-eastern coasts of Turkey

Table 2

Analysis of deviance table for the GAM model fitted to the catch per unit effort (CPUE) data of the longline

fishery of swordfish, Xiphias gladius, along the south-eastern coasts of Turkey in relation to Moon phases

\begin{tabular}{lccc}
\hline \multirow{2}{*}{ Parameter } & \multicolumn{3}{c}{ GAM } \\
\cline { 2 - 4 } & df & $F$ & $P$ \\
\hline Moon phase & 1 & 0.367 & 0.547 \\
Bait type & 4 & 0.549 & 0.700 \\
Area & 6 & 1.586 & 0.165 \\
s(Year) & 2.017 & 2.966 & 0.037 \\
s(Month) & 1.744 & 1.729 & 0.187 \\
s(Depth) & 1.815 & 1.517 & 0.250 \\
s(SST) & 1.000 & 0.110 & 0.741 \\
\hline
\end{tabular}

$\mathrm{df}=$ degrees of freedom, $F=F$-value, $P=P$-value, $\mathrm{s}(x)=$ smoother function of the corresponding independent variable, SST $=$ sea surface temperature. 
allocation of fishing effort (Hilborn and Walters 1992, Harley et al. 2001). Because of this, a pure yearly trend that is representative of the abundance index must be extracted by adjusting various factors (such as lunar phase, SST, area, bait type etc.) that change over the years and bias the raw CPUE trend (Okamura et al. 2018). Zuur et al. (2009) stated that it could be achieved by the use of GLMs (generalized linear models), GLMMs (generalized linear mixed effects models), and GAMs (generalized additive models).

In this study, the CPUE values ranged from 0 to $700 \mathrm{~kg}$ $\cdot 1000$ hooks $^{-1}$ with a mean $( \pm \mathrm{SE})$ of $176.1 \pm 15 \mathrm{~kg} \cdot 1000$ hooks $^{-1}$. The highest value of $700 \mathrm{~kg} \cdot 1000$ hooks $^{-1}$ was recorded in 2009 during a light period of the Moon. Other authors working in other Mediterranean areas (Di Natale et al. 1995, Relini et al. 2008) have reported mean CPUE values that were generally lower than the current estimate (Table 3). Probably, the ban of the swordfish driftnet fishery, implemented in Turkey in 2011, has favoured catch rate increases of the swordfish longline fishery.

Although the range of depth was between $65 \mathrm{~m}$ and $3000 \mathrm{~m}$ in this study, the hook position ranged from 5 to

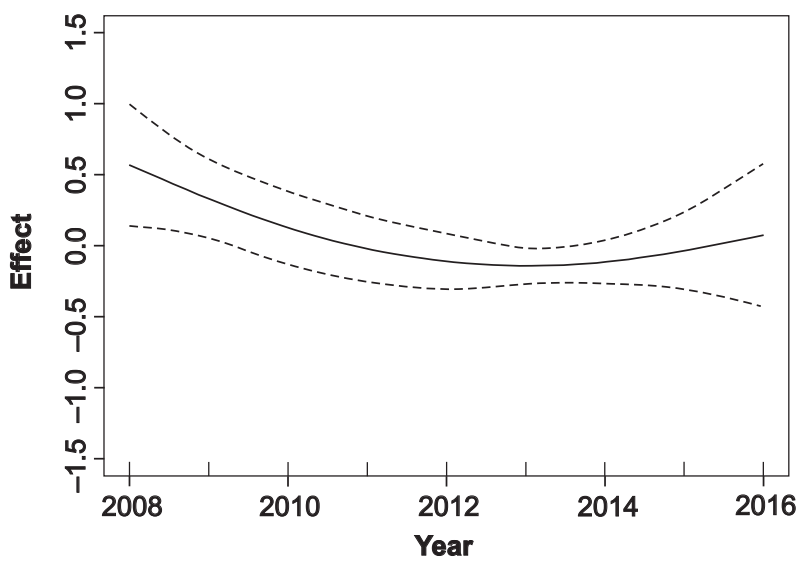

Fig. 5. GAM estimated effect of year on the catch per unit effort (CPUE) rates for of the surface longline fishery of swordfish, Xiphias gladius, along the south-eastern coasts of Turkey; dotted lines correspond to the $95 \%$ confidence intervals of the estimates
$30 \mathrm{~m}$ of depth (Akyol and Ceyhan 2010). Regardless of the predicted hook position, hooks fished between 40 and $60 \mathrm{~m}$ for most of the time in oceanic studies (Bigelow et al. 2006, Rice et al. 2007). Rice et al. (2007) also stated that some hooks were demersed as deep as $127 \mathrm{~m}$. In this study, the hooks deployed in shallower than those of previous studies and it was usually operated in the same layer of the sea surface in all fishing areas of this study. Thus, there is no statistical difference between fishing areas and between depths of locations where fishing operations were performed.

Lerner et al. (2013) reported that the swordfish spent $90 \%$ of the time from 8 to $20^{\circ} \mathrm{C}$ (median temperature: 8.5 $13.3^{\circ} \mathrm{C}$ during day time; $23.6-26.2^{\circ} \mathrm{C}$ during night time). In this study minimum, maximum and mean SST were $16.0,27.2$, and $18.6 \pm 0.32^{\circ} \mathrm{C}$, respectively. As it is expected that the narrow SST range in the eastern Aegean Sea did not affect the CPUE because, SST, current, and thermocline are important factors for swordfish shoaling that would be greater in dynamic oceanographic areas such as the equatorial Pacific or western boundary currents (Bigelow et al. 2006).

The following fish species were used as baits: sardines, squids, horse mackerels, round sardinella, and Atlantic chub mackerel although mackerel were the most common ones. Fishermen, however, prefer the use of mixed bait due to higher availability and lower price (especially regarding squids). Thus, the bait did not affect the CPUE in this study. Amorim et al. (2015) reported that there were statistically important differences between mackerel and squid as bait as well as between hook types. On the other hand, the higher catchability of swordfish with hooks baited with squid, might in part be related to its diet. Our results are different from Amorim et al. (2015) due to the baiting hooks with mixed species and choosing mackerel as the main bait.

It has been suggested that the depth distribution of swordfish is altered in response to the percentage of light due to the importance of swordfish vision in feeding (Carey and Robinson 1981). Hence, it is expected that the lunar phase could affect the catches of the swordfish longline fishery.

Table 3

Catch per unit effort (CPUE) values for of the surface longline fishery of swordfish, Xiphias gladius, in the Mediterranean

\begin{tabular}{lccl}
\hline \multirow{2}{*}{ Locality } & \multicolumn{2}{c}{ CPUE } & \\
\cline { 2 - 3 } & Range & Mean & \\
\hline Gulf of Taranto, Ionian Sea & $54.2-98.3$ & - & \\
Tyrrhenian Sea and Strait of Sicily & $22.10-138.70$ & 101.03 & De Metrio and Megalofonou 1988 \\
North-western Mediterranean & $64.84-169.60$ & 116.46 & Di Natale et al. 1995 \\
Tyrrhenian Sea and Strait of Sicily & $90.04-203.21$ & - & Tserpes et al. 2008 2011 \\
Eastern Mediterranean & $77.39-245.18$ & - & Tserpes et al. 2011 \\
Eastern Mediterranean & $15.6-27.8$ & - & Erdem and Akyol 2005 \\
Eastern Mediterranean & $0-700$ & 179.6 & Ceyhan and Akyol 2014 \\
Eastern Mediterranean & - & 131 & Tüzen et al. 2013 \\
Eastern Mediterranean & $31.23-479.48$ & - & Ceyhan et al. 2015 \\
Eastern Mediterranean & $0-700$ & 176.1 & This study \\
\hline
\end{tabular}


The presently reported study demonstrated that the lunar effect on swordfish CPUE was not statistically significant, while a series of other studies have provided varying and sometimes contradictory results. Bigelow et al. (1999) postulated that lunar phases might, in fact, affect vulnerability to the fishing gear, since the fish either alter their vertical distribution or have more enhanced visual acuity. In the Atlantic, the most successful catches were observed when the Moonlight intensity was higher (nights with full Moon), followed by nights with first quarter (Neves dos Santos and Garcia 2005). Poisson et al. (2010) have also reported the highest swordfish CPUE rates occurring during the first and last quarters of the lunar cycle. Orbesen et al. (2017) also observed that the nighttime swordfish catch rates were the highest during the dark period in the Gulf of Mexico. Conversely, Podestá et al. (1993), similarly to the presently reported study, could not demonstrate significant correlation between CPUE and lunar illumination. Furthermore, HernandezMilian et al. (2008) reported weakly significant relations between swordfish catches and both cloud cover, as well as the interaction between lunar phase and cloud cover. In the swordfish gillnet fishery operating in the central Mediterranean Sea, Di Natale and Mangano (1995) showed that the lowest catch rates were occurring during the full Moon. Akyol (2013) reported that the highest CPUE rates of the Turkish swordfish gillnet fishery were observed around the new Moon phase, while the highest rate $\left(300 \mathrm{~kg} \cdot \mathrm{km}^{-1}\right)$ was observed in May 2009. Poisson et al. (2010) stated that the absence of a consistent catch pattern in association with lunar phases might be related to prey availability. Di Natale and Mangano (1995) discussed that CPUE variations with lunar phase could be related to the behavioural adaptation of swordfish to different ambient light or to changes in the vertical distribution of cephalopods (important swordfish prey) caused by the full Moon. The influence of the lunar cycle on catchability can also be related to changes induced to tides and seacurrents (Omori 1995, Ward and Hindmarsh 2007). In some way, CPUE variations could be also related to changes of fishing intensity based upon preconceived opinions of the fishermen regarding the effect of lunar phase on catch rates.

In conclusion, it seems that the mechanism relating swordfish CPUE variations to the lunar cycle involves several factors, making it difficult to identify direct relations. Further studies are needed to better clarify the impact of the lunar phase on the longline gear, considering also additional parameters, such as light transition, prey abundance, physico-chemical characteristics of the marine environment, and the soak time of the gear.

\section{ACKNOWLEDGEMENTS}

This study was funded by the Turkish Scientific and Technological Research Council (TUBITAK Project No. 108O210) and the Ege University Science and Technology Center (EBILTEM Project No. 2009/BIL/019). We also thank skippers of swordfish fishing boats for giving us the opportunity to work freely on board.

\section{REFERENCES}

Akyol O. 2013. The influence of the Moon phase on the CPUEs of swordfish gillnet fishery in the Aegean Sea, Turkey. Turkish Journal of Fisheries and Aquatic Sciences 13 (2): 355-358. DOI: 10.4194/1303-2712-v13_2_18

Akyol O., Ceyhan T. 2010. Türkiye denizlerinde kullanılan pelajik kılıç paragatları. [Pelagic longlines for swordfish, used in Turkish seas.]. Ege University Journal of Fisheries and Aquatic Sciences 27 (4): 149156. [In Turkish.]

Amorim S., Santos M.N., Coelho R., FernandezCarvalho J. 2015. Effects of 17/0 circle hooks and bait on fish catches in a Southern Atlantic swordfish longline fishery. Aquatic Conservation: Marine and Freshwater Ecosystems 25 (4): 518-533. DOI: 10.1002 aqc. 2443

Anonymous 1999. Guidelines for the Routine Collection of Capture Fishery Data. FAO Fisheries Technical Paper No. 382. FAO, Rome.

Anonymous 2017a. [FishStatJ] Fishery and aquaculture statistics. Global capture production 1950-2015. In: Fisheries and Aquaculture Department. FAO, Rome. [Accessed on 7 December 2017.] http://www.fao.org/ fishery/statistics/software/fishstatj/en

Anonymous 2017b. Report of the 2016 Mediterranean Swordfish Stock Assessment Meeting (Casablanca, Morocco, 11-16 July 2016). International Commission for the Conservation of Atlantic Tunas. Collective Volume of Scientific Papers 73 (3): 1005-1096. https:// www.iccat.int/Documents/Meetings/Docs/2016 SWO_MED_SA_REPORT_ENG.pdf

Bigelow K.A., Boggs C.H., He X. 1999. Environmental effects on swordfish and blue shark catch rates in the US North Pacific longline fishery. Fisheries Oceanography 8 (3): 178-198. DOI: 10.1046/j.13652419.1999.00105.x

Bigelow K., Musyl M.K., Poisson F., Kleiber P. 2006. Pelagic longline gear depth and shoaling. Fisheries Research 77 (2): 173-183. DOI: 10.1016/j. fishres.2005.10.010

Carey F.G., Robinson B.H. 1981. Daily patterns in the activities of swordfish, Xiphias gladius, observed by acoustic telemetry. Fishery Bulletin 79 (2): 277-292.

Ceyhan T., Akyol O. 2014. On the Turkish surface longline fishery targeting swordfish in the eastern Mediterranean Sea. Turkish Journal of Fisheries and Aquatic Sciences 14 (3): 825-830. DOI: 10.4194/13032712-v14_3_25

Ceyhan T., Tserpes G., Akyol O., Ortiz de Urbina J.M. 2015. Analysis of Turkish swordfish (Xiphias gladius) catch rates in the eastern Mediterranean. International Commission for the Conservation of Atlantic Tunas. Collective Volume of Scientific Papers 71 (5): 19982005.

Damalas D., Megalafonou P., Apostolopoulou M. 2007. Environmental, spatial, temporal and operational effects on swordfish (Xiphias gladius) catch rates of eastern Mediterranean Sea longline fisheries. Fisheries Research 84 (2): 233-246. DOI: 10.1016/j.fishres.2006.11.001 
De Metrio G., Megalafonou P. 1988. Catch, size distribution, growth and sex ratio of swordfish (Xiphias gladius L.) in the Gulf of Taranto. FAO Fisheries Reports No. 394. FAO, Rome.

de la Serna J.M., Alot E., Rivera E. 1992. Análisis de las CPUEs por grupos de tallas del pez espada (Xiphias gladius) capturado con artes de superficie y enmalle a la deriva en el área del Estrecho de Gibraltar, durante los años 1989 y 1990. Relación con la fase lunar y otros factores ambientales. International Commission for the Conservation of Atlantic Tunas. Collective Volume of Scientific Papers 39 (2): 626-634.

Dewar H., Prince E.D., Musyl M.K., Brill R.W., Sepulveda C., Luo J., Foley D., Orbesen E.S., Domeier M.L., Nasby-Lucas N., Snodgrass D., Laurs R.M., Hoolihan J.P., Block B.A., McNaughton L.M. 2011. Movements and behaviors of swordfish in the Atlantic and Pacific Oceans examined using pop-up satellite archival tags. Fisheries Oceanography 20 (3): 219-241. DOI: 10.1111/j.1365-2419.2011.00581.x

Di Natale A., Mangano A., Navarra E., Schimmenti G., Valastro M. 1995. Swordfish (Xiphias gladius L.) longline fishing in the Tyrrhenian Sea and in the Strait of Sicily: 1992 Report. International Commission for the Conservation of Atlantic Tunas. Collective Volume of Scientific Papers 44 (1): 249-254.

Di Natale A., Mangano A. 1995. Moon phases influence on CPUE: a first analysis of swordfish driftnet catch data from the Italian fleet between 1990 and 1991. International Commission for the Conservation of Atlantic Tunas. Collective Volume of Scientific Papers 44 (1): 264-267.

Draganik B., Cholyst J. 1987. Temperature and moonlight as simulators for feeding activity by swordfish. International Commission for the Conservation of Atlantic Tunas. Collective Volume of Scientific Papers 27: 305-314.

Erdem M., Akyol O. 2005. Fethiye yöresinde (Akdeniz) paraketeyle kılıç (Xiphias gladius Linnaeus, 1758) avcılığı üzerine bir ön çalışma. [A preliminary study on longlining of swordfish (Xiphias gladius Linnaeus, 1758) in Fethiye Region (Mediterranean).] Ege University Journal of Fisheries and Aquatic Sciences 22 (1): 201-204. [In Turkish.]

Foster S.D., Bravington M.V. 2013. A Poisson-gamma model for analysis of ecological non-negative continuous data. Environmental and Ecological Statistics 20 (4): 533-552. DOI: 10.1007/s10651-0120233-0

Froese R., Pauly D. (eds.) 2018. FishBase. [Version 06/2018] www.fishbase.org

Harley S.J., Myers R.A., Dunn A. 2001. Is catch-perunit-effort proportional to abundance? Canadian Journal of Fisheries and Aquatic Sciences 58 (9): 1760-1772. DOI: 10.1139/f01-112

Hastie T.J., Tibshirani R.J. 1990. Generalized additive models. Monographs on Statistics and Applied Probability. Volume 43. Chapman and Hall/CRC, Boca Raton, London, New York, Washington DC.
Hernandez-Milian G., Goetz S., Varela-Dopico C., Rodriguez-Gutierrez J., Romón-Olea J., FuertesGamundi J.R., Ulloa-Alonso E., Tregenza N.J.C., Smerdon A., Otero M.G., Tato V., Wang J., Santos B., López A., Lago R., Portela J.M., Pierce G.J. 2008. Results of a short study of interactions of cetaceans and longline fisheries in Atlantic waters: Environmental correlates of catches and depredation events. Hydrobiologia 612 (1): 251-268. DOI: 10.1007/s10750-008-9501-2

Hilborn R., Walters C.J. 1992. Quantitative fisheries stock assessment: Choice, dynamics, and uncertainty. Springer Science + Business Media, Dordrecht, the Netherlands. DOI: 10.1007/978-1-4615-3598-0

Lecomte J.-B., Benoît H.P., Ancelet S., Etienne M.-P., Bel L., Parent E. 2013. Compound Poisson-gamma vs. delta-gamma to handle zero-inflated continuous data under a variable sampling volume. Methods in Ecology and Evolution 4 (12): 1159-1166. DOI: 10.1111/2041-210X.12122

Lerner J.D., Kerstetter D.W., Prince E.D., TalaueMcManus L., Orbesen E.S., Mariano A., Snodgrass D., Thomas G.L. 2013. Swordfish vertical distribution and habitat use in relation to diel and lunar cycles in the western North Atlantic. Transactions of the American Fisheries Society 142 (1): 95-104. DOI: 10.1080/00028487.2012.720629

Moreno S., Pol J., Munoz L. 1991. Influencia de la luna en el abundancia del emperador. International Commission for the Conservation of Atlantic Tunas. Collective Volume of Scientific Papers 35 (2): 508-510.

Nakamura I. 1986. Xiphiidae. Pp. 1006-1007. In: Whitehead P.J.P., Bauchot M.-L., Hureau J.-C., Nielsen J., Tortonese E. (eds.) Fishes of the Northeastern Atlantic and the Mediterranean. Volume 2. UNESCO, Paris.

Neves Dos Santos M., Garcia A. 2005. The influence of the Moon phase on the CPUEs for the Portuguese swordfish (Xiphias gladius L., 1758) fishery. International Commission for the Conservation of Atlantic Tunas. Collective Volume of Scientific Papers 58 (4): 1466-1469.

Okamura H., Morita S.H., Funamoto T., Ichinokawa M., Eguchid S. 2018. Target-based catch-per-uniteffort standardization in multispecies fisheries. Canadian Journal of Fisheries and Aquatic Sciences 75 (3): 452-463. DOI: 10.1139/cjfas-2016-0460

Omori K. 1995. The adaptive significance of a lunar or semi-lunar reproductive cycle in marine animals. Ecological Modelling 83 (1): 41-49. DOI: 10.1016/0304-3800(94)00082-S

Orbesen E.S., Snodgrass D., Shideler G.S., Brown C.A., Walter J.F. 2017. Diurnal patterns in Gulf of Mexico epipelagic predator interactions with pelagic longline gear: Implications for target species catch rates and bycatch mitigation. Bulletin of Marine Science 93 (2): 573-589. DOI: 10.5343/bms.2016.1008

Podestá G.P., Browder J.A., Hoey J.J. 1993. Exploring the association between swordfish catch rates and 
thermal fronts on U.S. longline grounds in the western North Atlantic. Continental Shelf Research 13 (2-3): 253-277. DOI: 10.1016/0278-4343(93)90109-B

Poisson F., Gaertner J.-C., Taquet M., Durbec J.-P., Bigelow K. 2010. Effects of lunar cycle and fishing operations on longline-caught pelagic fish: Fishing performance, capture time, and survival of fish. Fishery Bulletin 108 (3): 268-281.

R Core Team 2017. R: A language and environment for statistical computing. R Foundation for Statistical Computing, Vienna, Austria. http://www.R-project.org

Relini L.O., Palandri G., Garibaldi F., Cima C., Lanteri L., Relini M. 2008. A time series of swordfish longline CPUE in the northwestern Mediterranean: Search for exploitation and/or climatic factors influencing fish abundance. International Commission for the Conservation of Atlantic Tunas. Collective Volume of Scientific Papers 62 (4): 1097-1106.

Rice P.H., Goodyear C.P., Prince E.D., Snodgrass D., Serafy J.E. 2007. Use of catenary geometry to estimate hook depth during near-surface pelagic longline fishing: Theory versus practice. North American Journal of Fisheries Management 27 (4): 1148-1161. DOI: 10.1577/M06-114.1

Shono H. 2008. Application of the Tweedie distribution to zero-catch data in CPUE analysis. Fisheries Research 93 (1-2): 154-162. DOI: 10.1016/j.fishres.2008.03.006

Tserpes G., Peristeraki P., Di Natale A. 2003. Swordfish abundance trends in the Mediterranean. Pp. 101-108. In:
Mediterranean Biological Time Series. 11-14 June 2003, Split, Croatia. CIESM Workshop Monographs No. 22.

Tserpes G., Peristeraki P., Di Natale A., Mangano A. 2011. Analysis of swordfish (Xiphias gladius) catch rates in the central-eastern Mediterranean. International Commission for the Conservation of Atlantic Tunas. Collective Volume of Scientific Papers 66 (4): 1495-1505.

Tüzen M.T., Ceyhan T., Akyol O., Özkan C.M. 2013. Fethiye yöresinde (Akdeniz) pelajik Kılıç balığı paraketalarının av verimini arttırmak için kullanılan 1 şık çubukları üzerine denemeler. [Light stick trials, being used for boosting catch efficiency, on pelagic longline for swordfish in Fethiye region (Mediterranean Sea).] Ege Journal of Fisheries and Aquatic Sciences 30 (3): 133-137. [In Turkish.] DOI: 10.12714/egejfas.2013.30.03.07

Ward P., Hindmarsh S. 2007. An overview of historical changes in the fishing gear and practices of pelagic longliners, with particular reference to Japan's Pacific fleet. Reviews in Fish Biology and Fisheries 17 (4): 501-516. DOI: 10.1007/s11160-007-9051-0

Wood S.N. 2006. Generalized additive models: An introduction with R. Chapman and Hall/CRC, Boca Raton, London, New York.

Zuur A.F., Ieno E.N., Walker N.J., Saveliev A.A., Smith G.M. 2009. Mixed effects models and extensions in ecology with R. Springer, New York. DOI: 10.1007/978-0-387-87458-6

Received: 26 March 2018

Accepted: 3 August 2018

Published electronically: 30 September 2018 